to create a separate branch for forestry in the Board of Agriculture to deal with all forestry questions. There should be a Director of Operations, occupying the post of Joint Secretary or Assistant Secretary, to begin with. $\mathrm{He}$ should be a duly qualified forest expert, and be assisted by an adequate number of trained inspectors to supervise the field work. Wellconsidered plans of operations must at once be drawn up for each block, laying down the order of planting, deciding the selection of species to be planted according to the quality of the soil in each subdivision, drawing up a network of roads for future transport, to be constructed when required, and other matters.

\section{A NATIONAL STATUTORY BOARD OF SCIENCE AND INDUSTRY.}

$\mathrm{W}^{\mathrm{E}}$ have received for publication from the British Science Guild the following memorandum on the relations which should exist in future between the State and science, and suggesting that a national statutory Board of Science and Industry should be formed. The memorandum, which has been forwarded to the Government, is signed by some 220 of the most important representatives of industry, science, and education :-

The British Science Guild, which was founded in x 905 with the object of bringing home to all classes "the necessity of applying the methods of science to all branches of human endeavour, and thus to further the progress and increase the welfare of the Empire," is of opinion that the present European crisis affords a unique opportunity for impressing upon all who are engaged in the executive functions of government, as well as upon those who are concerned with industry and commerce, the paramount importance of scientific method and research in national affairs.

There has been much discussion upon these matters, and the following conclusions are submitted by the Guild as representing authoritative opinion :-

A. The material prosperity of the civilised world during the past century is mainly due to the application of science to practical ends.

B. While we stand high among all nations in capacity for original research, as represented by the output of our scientific workers, this capacity has been comparatively little utilised in British industry.

C. The State has neglected to encourage and facilitate scientific investigation, or to promote that cooperation between science and industry which is essential to national development.

D. Modern conditions of existence demand that instruction in science, and training in scientific method, should be a fundamental part of education.

E. The present control of all stages of educational work, from the primary school to the university, mostly by men who have an inadequate appreciation of the meaning and power of science, is largely responsible for the unsatisfactory preparation commonly provided for the work of life.

Since its foundation the British Science Guild has urged that, in the interests of national welfare, serious attention should be given to these defects, and steps taken to remedy them. The establishment of the scheme for the development of scientific and industrial research, under a Committee of the Privy Counicil, is a welcome recognition of the intimate relations between scientific investigation and industrial advance; and the Advisory Council which advises the Committee as to the expenditure of the sums provided by Parliament, amounting for the year I916-17 to 40 ,oool., has already been responsible for the institution of $r_{-}$ searches which should lead to most valuable industrial results. The outlook of the Council may, however, be extended profitably in several directions; for it should be even more comprehensive than that of the Development Commission, which provides for the development of rural industries, among other matters. This Commission, with the Board of Agriculture and Fisheries, and the Imperial Institute, which has recently been transferred from the Board of Trade to the Colonial Office, is not concerned directly with manufacturing industries, upon which so large a part of the nation's prosperity depends.

The field of the Privy Council Committee and its Advisory Council is thus distinct from that of any existing State department; and it should embrace all progressive industry, and science. It is suggested that a Board or Ministry is necessary to discharge the functions indicated in Clause $\mathrm{I}$. of the recommendations subjoined, in such a way as to fulfil modern requirements.

I. A national statutory Board of Science and Industry, the permanent staff of which should consist mainly of persons of wide scientific knowledge and business experience, should be established to :-

(I) Promote the co-ordination of industrial effort.

(2) Secure co-operation between manufacturers and all available laboratories of research.

(3) Co-ordinate, and be the executive centre of, such joint scientific committees as have been formed by the Royal Society, the Chemical Society, and various trade and educational associations.

(4) Undertake inquiries as to products and materials, and generally to serve as a national bureau of scientific and industrial intelligence.

(5) Collect and publish information of a scientific and technical character; and provide so far as possible for the solution of important problems bearing upon industry.

(6) Institute a number of paid advisory committees consisting of men of wide scientific knowledge assisted by expert investigators and technologists who should receive reasonable fees for their services.

(7) Organise scientific effort on the manufacturing side and in commercial relations with other countries.

(8) Arrange measures for the mobilisation of the scientific, industrial, and educational activities of the nation so as to ensure ready response to national needs and emergencies.

(9) Encourage investigation, and, where necessary, give financial aid towards the synthesis and artificial production of natural products and for other researches.

Such a Board would naturally administer the scheme of the Privy Council Committee, as well as take over certain functions of existing departments and boards.

The functions of the Board would be much the same as regards the promotion of scientific and industrial research and training, the co-operation of universities with industries through trade associations, and the maintenance of a record of scientific and technical experts, as outlined in the report on "British Trade after the War" by a Sub-Committee of the Board of Trade.

II. In all departments of State in which scientific work is carried on, adequate provision should be made for the periodical publication and wide distribution of bulletins, leaflets, and reports, so that increased public interest and attention may be encouraged in the results.

III. Every industrial undertaking, subsidised or otherwise assisted by the State, should have upon its board of directors men who possess expert scientific knowledge of the business in which they are engaged. 
IV. In order to develop industries which especially require the services of scientific workers, adequate remuneration and improved prospects should be offered by the Government, by municipal corporations, and by manufacturers to men who have received an effective scientific training. Means should be found of compensating and rewarding persons, whose researches have proved of decided national or public advantage without being profitable to themselves.

V. A knowledge of science should be regarded as an essential qualification for future appointments in the departments of the public service concerned with industrial; scientific, and technical developments. The Royal Commission on the Civil Service recommended in I9I4 that a Committee should be appointed to consider the present syllabus of subjects of examination for clerkships (Class I.). This Committee should be constituted without delay, and science as well as other branches of modern learning should be adequately represented upon it, and upon the Civil Service Commission itself.

VI. Measures should be taken to revise the educational courses now followed in the public schools and the Universities of Oxford and Cambridge.

VII. In elementary and secondary schools supervised by the Board of Education, more attention should be given to scientific method, observation, and experiment, and to educational handwork.

THE NATIONAL RESEARCH COUNCIL OF THE UNITED STATES.

Preliminary Statement.

$\mathrm{IN}$ response to a request from the President of 1 the United States, the National Academy of Sciences has undertaken to organise the scientific resources of educational and research institutions in the interest of national preparedness.

Public welfare and national security depend upon industrial progress and military efficiency, and these in turn result from practical applications of scientific knowledge. A superstructure, no matter how perfect, must have firm foundations, and thus the development of our industries must go hand in hand with the advancement of science through research.

Euclid, working out problems in pure mathematics in Alexandria, prepared the way for the calculations of the engineer. Galileo, discovering the satellites of Jupiter, convinced the world of the truth of the Copernican theory, broke down absurd medieval conceptions which prevented scientific progress, and stimulated exploration and advance in every field. Pasteur, studying the optical properties of certain crystals with no thought of practical result, was led to his investigations of bacteria and his epoch-making discoveries for the benefit of mankind.

Thus scientific research in the laboratory, whether for the advancement of knowledge or for direct industrial application, is a most fundamental form of national service, which should be encouraged by every possible means. Since the beginning of the war this fact has been recognised in England by the creation of a Scientific Council, and in Australia by the establishment of a National Institute of Science and Industry. Both bodies will devote their efforts to the promotion of scientific and industrial research.

No. 2440, VOL. 97]
Organisation of the National Research Council.

During the Civil War the need of scientific advice was clearly recognised by our Government. Accordingly the National Academy of Sciences was chartered in 1863 by Act of Congress, which stipulated that "the Academy shall, whenever called upon by any department of the Government, investigate, examine, experiment, and report upon any subject of science or art. ..." During the war, and frequently in later years, the Academy has been consulted by Congress, by the President, and by various members of his Cabinet.

The Naval Consulting Board, recently appointed by the Secretary of the Navy, has recommended the establishment of a naval experimental and testing laboratory and taken steps of far-reaching importance in the mobilisation of the industrial resources of the nation. The National Academy is now requested by the President to organise the extensive scientific resources of existing research laboratories in the interest of preparedness. To this end it has establishe'd a National Research Council.

The purpose of the Council is to bring into co-operation existing Governmental, educational, industrial, and other research organisations, with the object of encouraging the investigation of natural phenomena, the increased use of scientific research in the development of American industries, the employment of scientific methods in strengthening the national defence, and such other applications of science as will promote the national security and welfare.

Membership.-The Council will be composed of leading American investigators and engineers, representing the Army, Navy, Smithsonian Institution, and various scientific bureaux of the Government; educational institutions and research endowments; and the research divisions of industrial and manufacturing establishments.

In order to secure a thoroughly representative body, the members of the Council are being chosen in consultation with the presidents of the American Association for the Advancement of Science, the American Philosophical Society, the American Academy of Arts and Sciences, the American Association of University Professors, and the Association of American Universities, and with the advice of a special committee representing the American Society of Civil Engineers, the American Institute of Mining Engineers, the American Society of Electrical Engineers, and the American Chemical Society. Members of the Cabinet will be asked to name the representatives of the various departments of the Government.

Research committees of two classes will be appointed: central committees, representing various departments of science, comprised of leading authorities in each field, selected in consultation with the president of the corresponding national society; local committees in co-operating institutions engaged in research.

The Council of the Academy will recommend to the National Research Council the following plan of procedure, subject to such modification as may seem desirable :- 